\title{
Konstruksi Konsep Diri Sepasang Remaja dalam Film Dua Garis Biru
}

\author{
Rahayu Kurnia Kinasih, Farid Rusdi \\ rahayu296@gmail.com,farid@fikom.untar.ac.id
}

Fakultas Ilmu Komunikasi Universitas Tarumanagara

\begin{abstract}
Movie is one of the most important mass media in describing a social reality that aired on cinema, and then the message of the story content of a movie can be well received by the audience. The development of youth-themed movies is increasingly diverse in building an interesting story. One of them is Dua Garis Biru, a movie depicting a pair of teenagers who have intercourse outside the marriage. Through the movie, researchers are very interested in conducting research as the main focus on the concept of teenage children. Therefore, the authors use psychological theories to support the results of the authors' research, and use the research methods of analysis of discourse expressed by Teun A. Van Dijk. The results of the research found were the perpetrators of premarital sex in the Dua Garis Biru movie are constructed as a teenager representing the reality of premarital sex teenagers to still be able to form a positive self-concept. The development of the children's concepts can be assisted by how the family, especially the role of parents in establishing good communication, as well as providing education about the health of sexuality and reproduction to children.
\end{abstract}

Keywords: discourse analysis, self concept, teen movies.

\begin{abstract}
Abstrak
Film merupakan salah satu media massa yang paling berperan dalam menggambarkan suatu realitas sosial yang ditayangkan di layar bioskop, kemudian pesan dari isi cerita sebuah film dapat diterima dengan baik oleh penonton. Perkembangan film yang bertemakan remaja, semakin beragam dalam membangun suatu cerita yang menarik. Salah satunya adalah film Dua Garis Biru yang menggambarkan sepasang remaja yang melakukan hubungan badan di luar pernikahan. Melalui film tersebut, peneliti sangat tertarik untuk melakukan penelitian sebagai fokus utamanya tentang konsep diri anak remaja. Oleh karena itu, penulis menggunakan teori-teori psikologi untuk mendukung hasil penelitian penulis, dan menggunakan metode penelitian analisis wacana yang dikemukakan oleh Teun A. Van Dijk. Hasil penelitian yang ditemukan ialah pelaku remaja seks pranikah dalam film Dua Garis Biru dikonstruksikan sebagai remaja yang mewakili realitas remaja seks pranikah untuk tetap bisa membentuk konsep diri positif. Perkembangan konsep diri anak dapat dibantu melalui bagaimana keluarga, terutama peran orangtua dalam membangun komunikasi yang baik, serta memberikan edukasi tentang kesehatan seksualitas dan reproduksi kepada anak.
\end{abstract}

Kata Kunci: analisis wacana, film remaja, konsep diri.

\section{Pendahuluan}

Remaja adalah masa pertumbuhan dan perkembangan atau transisi seseorang dari masa anak-anak menuju usia dewasa. Perubahan yang biasa dialami pada masa remaja mulai dari sikap, cara berpikir, dan fisik. Menurut data World Health Organization (WHO) bahwa umur remaja rentang mulai dari usia 10 hingga 19 tahun. Pada masa remaja didominasi atas anak sekolah SMP dan SMA yang sudah pubertas 
atau akil balig. Ketika seseorang sudah mengalami pubertas, maka akan memiliki hasrat seksual dan memiliki keinginan untuk memuaskan hasrat seksualnya. Sokowati (2018) menyatakan di satu sisi organ reproduksi seseorang sudah berfungsi, namun menurut norma sosial dan agama hubungan seks tidak boleh dilakukan di luar pernikahan. Beberapa diantara mereka dalam menyikapi hasrat seksualnya dengan cara membuka film-film pornografi, buku-buku yang tidak senonoh, dan informasiinformasi lainnya yang terkait dengan seksualitas. Menurut Louisa dan Setyanto (2014) bahwa melalui penyingkapan seseorang akan mendapatkan berbagai manfaat baik bagi dirinya sendiri maupun bagi hubungan yang dibangun dengan lawan komunikasinya, diantaranya meliputi pengetahuan diri, keefektifan dalam berkomunikasi dan membangun relasi dengan orang lain, dan kesehatan psikologis. Penyingkapan diri juga merupakan tindakan yang beresiko, diantaranya meliputi risiko personal (bagi dirinya), resiko berelasi, dan resiko professional (Louisa dan Setyanto, 2014). Oleh sebab itu, sangat penting untuk para pembimbing atau orang yang lebih tua dapat memberikan ajaran yang benar dalam memperkenalkan seksualitas, supaya remaja dapat mengetahui batasan-batasan yang harus dihindari akan perbuatan seks.

Tidak sedikit juga remaja yang memiliki hubungan pacaran dengan kekasihnya, sebagai salah satu alasan untuk pemuasan hasrat seksnya. Dengan melakukan hubungan badan, sebagai alasan karena adanya rasa sayang kepada kekasih. Alhasil, ada yang sampai mengalami kejadian kehamilan yang tidak dikehendaki. Oleh karena itu, peran media sangat penting dalam mempersuasi khalayak untuk dapat menghindari hal-hal yang tidak diinginkan.

Salah satunya adalah film, yang menjadi sarana untuk membangun suatu cerita baik fiksi/non fiksi yang menampilkan realitas sosial, cerita tersebut terdapat pesanpesan penting untuk disampaikan kepada penonton/khalayak. Menurut Prakoso (Romli, 2016) film adalah sebuah gambar hidup, hasil dari seonggok seluloid, yang diputar dengan menggunakan proyektor, lalu ditembakkan ke layar yang besar, kemudian dipertunjukkan di gedung bioskop. Dalam dunia perfilman terdapat beragam tema, seperti yang bertajuk remaja, horor, musikal, drama, dan lain-lainnya. Film tema remaja seringkali identik dengan anak sekolah berseragam SMA yang sedang mengenal cinta. Salah satunya pada film "Dua Garis Biru" yang cerita di dalamnya merupakan gambaran realitas atas fenomena remaja seks pranikah hingga terjadinya kehamilan. Sehingga film ini mengkonstruksikan bagaimana cara pelaku remaja dalam menangani peristiwa tersebut, yang dapat menghancurkan masa depannya. Melalui penanganan yang remaja hadapi, dapat menentukan perkembangan konsep diri sepasang remaja yang akan terbentuk. Penelitian ini bertujuan untuk mengetahui pembentukkan konsep diri sepasang remaja seks pranikah dalam menghadapi masalah kehamilan remaja.

\section{Metode Penelitian}

Penelitian ini akan dianalisis melalui Analisis Wacana yang dikemukakan oleh Teun A. Van Dijk. Model ini kerap disebut sebagai "kognisi sosial". Istilah ini diadopsi dari pendekatan lapangan psikologi sosial, terutama untuk menjelaskan struktur dan proses terbentuknya suatu teks. Menurut van Dijk penelitian atas wacana cukup hanya didasarkan pada analisis atas teks semata, karena teks hanya hasil dari suatu praktik produksi yang harus juga diamati (Sobur, 2009). 
Rahayu Kurnia Kinasih, Farid Rusdi: Konstruksi Konsep Diri Sepasang Remaja dalam Film Dua Garis Biru

Untuk melakukan penelitian film Dua Garis Biru, melalui analisis wacana, akan mengambil beberapa potongan adegan, kemudian teks skenario dalam percakapan di adegan tersebut dianalisis menggunakan 6 elemen wacana, yaitu Tematik, Skematik, Semantik, Sintaksis, Stilistik, dan Retoris.

\begin{tabular}{|c|c|c|}
\hline Struktur Wacana & Hal yang Diamati & Elemen \\
\hline Struktur Makro & $\begin{array}{l}\text { Tematik } \\
\text { (Apa yang dikatakan?) }\end{array}$ & Topik \\
\hline Superstruktur & $\begin{array}{l}\text { Skematik } \\
\text { (Bagaimana pendapat } \\
\text { disusun dan dirangkai?) }\end{array}$ & Skema \\
\hline Struktur Mikro & $\begin{array}{l}\text { Semantik } \\
\text { (Apa makna yang ingin } \\
\text { disampaikan?) }\end{array}$ & $\begin{array}{l}\text { Latar, detail, ilustrasi, } \\
\text { makna, praanggapan, } \\
\text { nominalisasi }\end{array}$ \\
\hline Struktur Mikro & $\begin{array}{l}\text { Sintaksis } \\
\text { (Bagaimana pendapat yang } \\
\text { disampaikan?) }\end{array}$ & $\begin{array}{l}\text { Koherensi, bentuk kalimat, } \\
\text { kata ganti }\end{array}$ \\
\hline Struktur mikro & $\begin{array}{l}\text { Stilistik } \\
\text { (Pilihan kata apa yang } \\
\text { dipakai?) }\end{array}$ & Kata kunci, kosakata \\
\hline Struktur Mikro & $\begin{array}{l}\text { Retoris } \\
\text { (Bagaimana dan dengan } \\
\text { cara apa pendapat } \\
\text { disampaikan?) }\end{array}$ & $\begin{array}{l}\text { Gaya, interaksi, ekspresi, } \\
\text { visual image }\end{array}$ \\
\hline
\end{tabular}

Selain itu, untuk mendukung hasil penelitian, dilakukan wawancara kepada narasumber yang memiliki ahli atau bidang yang dapat memahami penelitian ini, yakni seorang Psikolog Perkembangan Anak dan Remaja (Agustina).

\section{Hasil Temuan dan Diskusi}

Setelah melakukan penelitian dari beberapa adegan dari Film Dua Garis Biru yang penulis teliti, hasil temuan penulis sebagai berikut:

\begin{tabular}{ccl}
\hline No & Elemen Wacana & \multicolumn{1}{c}{ Penjelasan } \\
\hline 1. & Tematik & Film Dua Garis Biru mengangkat topik dari realitas \\
& & sosial, yang menceritakan suatu peristiwa remaja yang \\
& melakukan seks pranikah dengan kekasihnya, hingga \\
& mengakibatkan terjadinya kehamilan yang tidak \\
& diinginkan. Sepasang remaja dalam film ini dibangun \\
& menjadi remaja yang mampu dalam menghadapi masalah \\
& kehamilan remaja dan terbentuk konsep diri yang baik. \\
\hline 2. Skematik & Skema yang tersusun dalam film Dua Garis Biru, tiap \\
& adegan adanya penekanan pesan untuk mendukung \\
& adegan berikutnya. Sehingga cerita dari film ini, tercipta \\
& alur cerita maju. Mulai dari keceriaan sepasang remaja \\
& yang menjalani hubungan percintaan, batasan-batasan \\
& yang sudah mereka lewati seperti melakukan hubungan \\
\hline
\end{tabular}




\begin{tabular}{|c|c|}
\hline & $\begin{array}{l}\text { seks di kamar Dara, hingga konsekuensi yang akan } \\
\text { mereka genggam di masa depan. }\end{array}$ \\
\hline 3. Semantik & $\begin{array}{l}\text { Adegan-adegan dalam film Dua Garis Biru yang } \\
\text { dianalisis melalui semantik, adanya makna-makna } \\
\text { tertentu yang ingin disampaikan oleh pemain kepada } \\
\text { komunikan. Melalui teks skenario yang diucapkan oleh } \\
\text { para pemain, sehingga akan membentuk suatu wacana } \\
\text { untuk menggambarkan konsep diri remaja seks pranikah. } \\
\text { Salah satunya pada adegan kedua orangtua dari Bima dan } \\
\text { Dara yang berada di UKS, kalimat yang dilontarkan } \\
\text { Bima, "Saya akan tanggung jawab om, tante. Saya pasti } \\
\text { bakal nanggung Dara dan anak saya," menggambarkan } \\
\text { bagaimana konsep diri Bima dikonstruksikan positif. } \\
\text { Makna yang tersirat dari kalimat tersebut bahwa manusia } \\
\text { tidak boleh lari dari masalah yang telah diperbuat. }\end{array}$ \\
\hline 4. $\quad$ Sintaksis & $\begin{array}{l}\text { Teks skenario dalam adegan film Dua Garis Biru yang } \\
\text { dianalisis melalui wacana sintaksis, merupakan suatu } \\
\text { kalimat koheren yang menjelaskan atau menggambarkan } \\
\text { suatu keadaan. Terutama pada adegan Bima dan Ibunya, } \\
\text { melalui kalimat koheren yang dilontarkan oleh Ibu Bima } \\
\text { "Kalau Ibu aja perlahan-lahan bisa maafin kamu, apalagi } \\
\text { Allah" dapat menenangkan suasana hati Bima dan } \\
\text { membantu perkembangan konsep dirinya. }\end{array}$ \\
\hline 5. Stilistik & $\begin{array}{l}\text { Suatu gaya bahasa yang digunakan dalam film Dua Garis } \\
\text { Biru, sebagai sarana untuk menyampaikan suatu gagasan } \\
\text { dan keadaan serta perasaan yang dialami oleh } \\
\text { komunikator (pemain). Salah satunya pada adegan } \\
\text { Kakak Bima yang menggunakan bahasa kasar sebagai } \\
\text { kekesalan dan kekecewaan seorang Kakak kepada } \\
\text { Adiknya. }\end{array}$ \\
\hline 6. Retoris & $\begin{array}{l}\text { Adegan-adegan dalam film Dua Garis Biru yang } \\
\text { dianalisis melalui wacana retoris, adanya maksud untuk } \\
\text { menggambarkan suatu kondisi yang dapat membentuk } \\
\text { konsep diri remaja dalam menghadapi sebuah masalah } \\
\text { yang harus diselesaikan. Terutama pada adegan Dara } \\
\text { yang terbaring lemah di UKS, menggambarkan } \\
\text { kesedihan yang sedang dialaminya. }\end{array}$ \\
\hline
\end{tabular}

Melalui analisis wacana teks yang telah dilakukan, banyak diperlihatkan bagaimana film Dua Garis Biru mengkonstruksi remaja pelaku seks pranikah, kemudian terjadi kehamilan remaja, dan mengalami konflik-konflik yang dapat mempengaruhi konsep dirinya. Mulai dari kepanikan saat diketahui hamil, dan tanggapan dari orangtua serta sekolah, hingga risiko yang harus mereka hadapi. Film ini ingin menampilkan remaja menghadapi kehamilan yang tidak diinginkan, mengalami shock pada dirinya sehingga berencana untuk melakukan aborsi. Menurut psikolog perkembangan anak dan remaja, Agustina mengatakan bahwa remaja yang mengalami kasus hamil di luar nikah, tidak serta merta konsep diri yang terbangun menjadi negatif. Hanya saja bagaimana remaja dapat menyesuaikan dirinya pada 
suatu masalah yang seharusnya mereka hadapi dan selesaikan. Sehingga film ini mengkonstruksikan remaja seks pranikah menggagalkan aborsinya.

Dalam realitas mengenai isu kehamilan remaja, kemudian menjadi orangtua, merupakan sebuah kisah yang kerap terjadi di kalangan masyarakat. Namun, ternyata pentingnya sex education masih dianggap tabu untuk dibicarakan di dalam keluarga. Peran keluarga sangat penting untuk memberikan pengetahuan seks kepada anak, serta memberikan didikan yang baik untuk membangun konsep diri anak yang baik. Gina menjelaskan, melalui film tersebut, bagaimana seharusnya keluarga mengajarkan anak tentang seksualitas, mulai dari mengajak anak mengenali dirinya siapa, dan mengajarkan bagian tubuh mana yang boleh dan tidak boleh disentuh oleh orang lain, serta mengenali batasan dirinya dengan orang lain. Hal itu akan membantu perkembangan anak dalam membangun emosi diri, menjaga diri, serta penghargaan diri sendiri. Hal itu sesuai dengan teori faktor yang mempengaruhi perkembangan konsep diri anak yang dikemukakan oleh Saam dan Wahyuni (2014) bahwa faktor yang diperkirakan paling besar mempengaruhi perkembangan konsep diri anak salah satunya adalah keluarga dan peranan harga diri anak itu sendiri.

Sehingga konsep diri sepasang remaja dalam film Dua Garis Biru dikonstruksikan sebagai remaja yang memiliki konsep diri yang positif. adanya tandatanda yang membentuk identitas diri remaja yang baik seperti teori konsep diri positif yang dikemukakan oleh Brooks dan Emmart (Harapan dan Ahmad, 2016), yaitu:

1. Bima dan Dara berani mengambil keputusan dan mengakui kesalahannya atas terjadi kehamilan di luar pernikahan pada Dara.

2. Bima dan Dara sebagai remaja seks pranikah, mampu untuk mempertahankan kandungannya hingga melahirkan, serta mengatasi suatu konflik dalam penyerahan anak kepada orang lain. Kedua remaja yang tetap mengakui dirinya sebagai orangtua dari anak yang dikandung Dara.

3. Dara yang memiliki mimpi atau cita-cita untuk melanjutkan pendidikan ke Korea, ia tetap berjuang dan berusaha menyelesaikan SMA nya meskipun mengikuti UN paket C. Sementara Bima, yang mampu bertanggung jawab sebagai Bapak atas anak yang dikandung Dara.

\section{Kesimpulan}

Melalui analisis wacana Teun A.van Dijk, Bima dan Dara dalam film Dua Garis Biru telah menggambarkan proses perkembangan konsep diri remaja seks pranikah. kedua remaja yang harus menghadapi masalah yang terjadi yaitu kehamilan remaja pada Dara, mereka dapat menanganinya dan menyikapi konflik-konflik tersebut. Psikolog Agustina bahwa remaja seks pranikah tidak langsung membentuk konsep diri yang buruk, melainkan akan tetap adanya proses pembentukan konsep diri melalui cara adaptasi kedua remaja seks pranikah dalam menghadapi kehamilan remaja Dara. Konsep diri yang terbentuk kepada kedua remaja adalah terbangun positif.

\section{Ucapan Terima Kasih}

Peneliti ingin menyampaikan rasa terima kasih yang sebesar-besarnya kepada semua pihak yang ikut terlibat dalam penyusunan penulisan jurnal dan telah membantu peneliti selama proses penelitian ini berlangsung, yaitu: 
1. Kepada Psikolog Agustina dan Bapak Petrus D. Sitepu sebagai narasumber dalam penelitian ini yang telah meluangkan waktu untuk wawancara

2. Kepada kedua orangtua, Ibu dan Bapak tercinta, Arum Kusuma Wardani dan Ayun Kusuma Astuty selaku kakak penulis. Terima kasih atas seluruh doa dan dukungan yang tiada hentinya diberikan kepada penulis sehingga penulis dapat menyelesaikan penyusunan.

3. Desi, Nishya, Lia, Johanna, sebagai teman-teman seperjuangan satu Fakultas yang dari awal selalu memberikan dukungan kepada penulis dalam melakukan kerja praktek hingga penyusunan skripsi.

4. Ovika selaku sahabat penulis yang selalu memberikan dukungan, doa, dan hiburan kepada penulis.

5. Arie sebagai teman yang telah membantu penulis selama penyusunan skripsi.

\section{Daftar Pustaka}

Harapan, E., \& Ahmad, S. (2016). Komunikasi Antarpribadi. Jakarta: PT Raja Grafindo Persada.

Kementerian Kesehatan RI. (2108). Situasi Kesehatan Reproduksi Remaja. Diunggah 19 Agustus (2019) dari Kementerian Kesehatan Online: file:///C:/Users/USER/Downloads/infodatin\%20reproduksi\%20remaja-ed.pdf

Louisa, Riris., \& Setyanto, Yugih. (2014). Penyingkapan Diri Melalui Internet di Kalangan Remaja (Studi Komunikasi Antar Pribadi. Jurnal Komunikasi, vol 6, no 3, hal: 32

Romli, Khomsahrial. (2016). Komunikasi Massa. Jakarta: PT Grasindo.

Saam, Zulfan., \& Wahyuni, Sri. (2014). Psikologi Keperawatan. Jakarta: PT Raja Grafindo Persada.

Sobur, A. (2009). Analisis Teks Media : Suatu Pengantar Analisis Wacana, Analisis Semiotik dan Analisis Framing. Bandung: PT Remaja Rosdakarya.

Sokowati, Endah Muria. (2018). Wacana Perbedaan Gender Dalam Artikel Pendidikan Seks Remaja (Analisis Wacana Kritis Artikel Seksualitas Majalah Hai Edisi 1995-2004). Jurnal Komunikasi, vol 10, no 1, hal: 49-50. 